\title{
Jag du vi hej mamma pappa: en läsebok i förändring
}

\author{
Almqvist E Wiksells långlivade läseböcker $\mathrm{Nu}$ läser vi (1970) och \\ Vi läser (1989) har båda sitt ursprung $i$ den ännu äldre Nu ska vi \\ läsa (1948). De handlar alla tre om syskonen Tor och Lena och deras \\ familj och skolkamrater, successivt moderniserat med hjälp av nya \\ illustrationer och ny uppläggning.
}

Denna artikel studerar hur läsebokens versioner ändrat karaktär i takt med nya tiders samhälle och pedagogiska utgångspunkter. Artikeln utgör en bakåtblickande del av ett större projekt hemmahörande i diskussionen kring skolläsning kontra fritidsläsning: det handlar om nybörjarläsares nutida läseböcker och lättlästa böcker sedda i relation till den skönlitterära barnboken. Jag intresserar mig framför allt för böckernas form och struktur. För en renodlad studie av läseböckers samhällsskildring rekommenderas Ingerd Eilards avhandling Modern, svensk och jämställd (2008).

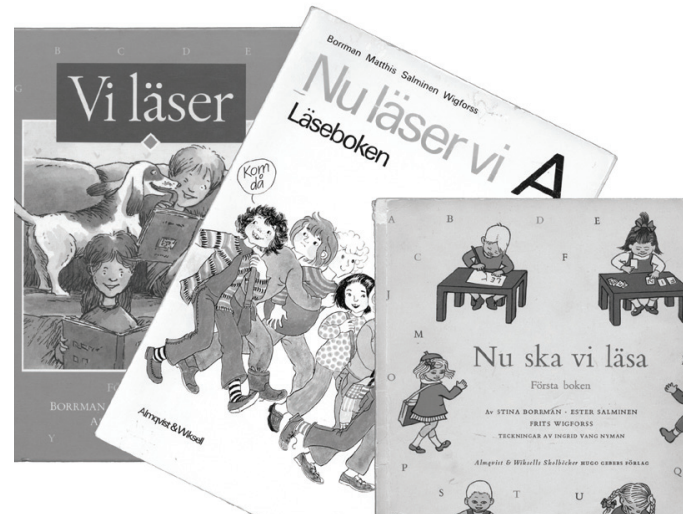

Omslag till Vi läser (1989), Nu läser vi (1977), Nu ska vi läsa (1948, återges med tillstånd av Saltkråkan AB. Eftertryck förbjudes.).

\section{Läsning och läseböcker}

Från att ha varit kyrkans och hemmets uppgift, blev läsundervisningen på 1800-talet skolans ansvar. Hur undervisningen i praktiken har gått till har varierat med nya rön och läroplaner (Längsjö \& Nilsson, kap.4). Samtidigt har läsmaterialet förändrats, men de flesta perioder har ändå krävt någon sorts särskilt material till hjälp i klassrummet. Det är här läseboken kommer in. Förr innebar "läsebok" en lärobok för alla ämnen, svenska, natur- och samhällskunskap - se t.ex. den kända Läsebok för folkskolan från 1868. Idag avser vi ofta snävare en skolbok menad som guide 
och redskap för att lära sig läsa. Ett typiskt innehåll är presentation av alfabetets bokstäver och texter som stegvis ökar i svårighetsgrad, från korta ord och fraser till längre stycken.

Den läsebok som här valts för närmare studium är genom sina många versioner tacksam för historisk belysning. Fokus ligger på de berättande lästexterna om Tor och Lena. Artikeln behandlar första årskursens huvudbok. Jag berör inte övrigt material; lärarhandledning, träningshäften etc. Egentligen rör det sig ändå om hela fem böcker, inte tre. Nu ska vi läsa (1948) höll sig ganska konstant under sin levnad (till nionde upplagan 1967), men Nu läser vi (1970) utkom i avsevärt reviderad upplaga 1977, och Vi läser (1989) fick så sent som 2005 en ny, förändrad form.

\section{Nu ska vi läsa (1948)}

1800-talets många läsläror är systematiskt uppbyggda och kanske inte alltid så roliga som läsning betraktat (se tidiga exempel i Lindell). I början av 1900-talet syns en strävan mot mer barnanpassat material (Vad händer med läsningen? 2007, 29). Ett klassiskt exempel i denna anda är Anna Maria Roos Sörgården (1912), avsedd för småskolans första år. Till skillnad från tidigare läseböcker innehåller den, genom sina textstycken om återkommande personer och en specifik trakt, en sorts sammanhängande berättelse (i samma lärobokssatsning utges ju också, för äldre elever, bl.a. den skönlitterära Nils Holgerssons underbara resa genom Sverige). Till det lyckade resultatet bidrar den skönlitterära författaren och omsorgen om bilderna (se Löfgren, 208f, 217-227). Bokens för sin tid läsvänliga kombination av läslära och läsupplevelse sätter tonen för efterföljande läseböcker. Bland annat $N u$ ska vi läsa från 1948 har en liknande uppbyggnad. Den börjar med introduktion av ett tiotal bokstäver med tillhörande ordexempel, sedan växlar läsläre-element med enkla texter i tydlig progression.

Redan den typiska titeln $\mathrm{Nu}$ ska vi läsa anger hur boken ska tolkas. Detta riktar sig direkt till läsaren i en gemensam klassrumsaktivitet: nu ska vi läsa. Omslaget av Ingrid Vang Nyman betonar också skolsituationen. Diverse läs- och skrivaktiviteter pågår, och Tor och Lena på var sida om titeln är på väg inåt i bild, mot bänkarna och de andra barnen, men med blick och vinkning ut mot läsaren. Skolan är över huvud taget ett vanligt motiv i läseböcker ända sedan starten (se Lindell) - naturligt nog, det är ju den spännande nya livssituation som läsaren befinner sig i. Skolbarnen från omslaget återkommer då och då inne i boken, pysslande vid sina bänkar. Mot det gula omslaget är dessutom bokstäver utströdda, och på insidan av pärmen och 
på titelsidan understryks den läslärande funktionen med alfabetet $\mathrm{i}$ flera upplagor. Bokstäverna introduceras sedan med hjälp av rimmade strofer som direkt anknyter till abc-bokstraditionen. Stroferna tar inte hänsyn till övrig texts svårighetsnivå och lyckas så vara lite mer uppsluppna, något att lära sig utantill även för dem som inte kan läsa själva.

När det gäller berättelsen om Tor och Lena leds vi in i den via de inbjudande barnen på omslaget, presentation av familjemedlemmarna s.20 och så en matbordsscen s.21. Den följs av flera episoder, aldrig mer än en sida långa, omväxlande ute och inne, fristående utan särskild inbördes ordning men med given utgångspunkt $i$ hemmet och familjen. Framför allt genom bilderna ges ett starkt intryck av närhet, mellan vuxen och barn. Både en far och en mor avbildas tidigt med ett barn i famnen. Familjen gör saker tillsammans. Barnen kommer hem från och går till skolan, mor leker med Lena, barnen läser och ritar. Så småningom introduceras flera barn, men aldrig så att man som läsare har något behov av att hålla reda på vem som är vem - Vang Nymans illustrationer bygger också mycket på stilisering.

Möjligheten att berätta något mer utförligt är naturligtvis begränsad av kravet på enkelhet och texter anpassade till redan introducerade bokstäver - lite O mor! Orm! kommer man inte undan. Tydliga markörer av traditionell, konstlad läseboksstil är exempelvis övervikten av enstaviga ord och just begränsningen till de mest frekventa bokstäverna. Men med små medel kan faktiskt texten höja sig över det banala, även utan hjälp av bild. Se texten på s.45:

Far tar ål i ån.

Tor ror åt far.

Far får så fina ålar.

Mor kokar ålen sen.

Ål är fet mat.

Förstärkningsordet" så" är det som gör hela texten. Läsarens engagemang vaknar. I och med "så" finns plötsligt en avsändare, förslagsvis Tor som skrivit själv i skolan. Det sista påståendet ekar då av citerad källa - här är fakta som Tor återberättar. Och med Tor som upphovsman får texten en rimlig funktion, ett ursprung. Problematiskt blir omnämnandet av honom själv i tredje person, men det råkar vara ett vanligt drag i äldre läsebokstexter, förorsakat av att bokstäverna J och G inte är inlärda än - och kanske kan det också användas som bekräftelse på att texten är Tors? Även han är ju mitt i processen att lära sig läsa och skriva.

Far ror och mor är rar. I Nu ska vi läsa är det fortfarande far som lär Tor att ro, och mor som tillagar den fångade fisken. Den borgerliga 
familjeidyllen och rollfördelningen blir tydlig, och ofrivilligt lustig i dagens ögon, när familjemedlemmarna håller upp varsin representativ sak: mor med sitt obligatoriska förkläde en sil, far (iklädd tredelad kostym!) en fil, Tor ett lok och Lena en ros (s.25). Som Clarhäll påpekar kan de tidigt introducerade orden "ren" och "rar" även känneteckna estetiken och uppfostringsidealet (Clarhäll, 68). Men observera att på samma sida som ordexemplen "ren" och "fin" står även "lek" - inte att förglömma (Nu ska vi läsa, 25). Och bilderna visar också barn som hoppar hage, bygger snögubbe, leker med leksakståg, flyger drake, kalasar, åker trampbil (och för all del även går i skolan, torkar disk och kammar håret). Vang Nymans Pippi-gestalt spökar oundvikligen i bakhuvudet (se t.ex. flickan som flätar håret, s.50), trots diametralt olika texter. Kanske det är lite av Pippi Långstrumps obändiga kraft och leklusta som här har smittat av sig på Tor och Lena, alias Tommy och Annika. Och inte bara Tor, utan även Lena får faktiskt lära sig att ro, liksom stå inför klassen och berätta - och sitter inte Pippi med sina karakteristiska flätor där på första raden och lyssnar! (s.87).

Så boken är inte bara skolplikt. Det mer lustfyllda finns också med, inte minst i bilderna, för det är framför allt Vang Nymans insats i uppmuntrande fyrfärg som står för det nymodiga och livsbejakande (jfr Clarhäll, 68f). Det samlade intrycket av Nu ska vi läsa är ändå färdighetsträning mer än berättelse om Tor och Lena. Den pedagogiska funktionen är överordnad och det är rätt mycket smörgåsbord över det hela, ingen direkt helhet att bläddra igenom. Till det bidrar även bildernas genomgående lilla format, utan större sammanhang men med desto mer vit sidyta. Incitamenten är få till funderingar utöver det begränsade textoch bildinnehållet. Stuket är fortfarande lydigt lärande. Det blir inte heller någon riktig avslutning för det som kan tänkas ha engagerat eleven, Tor och Lena-episoderna. Barnen får visserligen som sista aktivitet

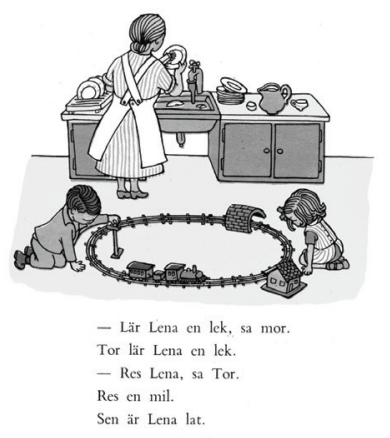
${ }^{24}$ göra något så roligt som att gå på cirkus, men det sker på näst sista sidan, och se-
Illustration av Ingrid Vang Nyman ur Nu ska vi läsa (1948). Återges med tillstånd av Saltkråkan AB. Eftertryck förbjudes. 
dan avrundas hela boken med ett par intetsägande, fristående texter till bokstaven X. Slutintrycket är därmed fortfarande läslära snarare än upplevelseläsning: nu har vi läst hela boken, nu kan vi alla bokstäver och nu, först $n u$ ska vi läsa.

\section{Nu läser vi (1970 och 1977)}

Mellan Nu ska vi läsa och Nu läser vi infaller en helt ny skolform med tillhörande läroplan (folkskola blir grundskola, Lgr62 och Lgr69), men när det gäller undervisningsmetodik råder fortfarande en behavioristisk syn med systematisk färdighetsträning, läsning och skrivning skilda åt, läsundervisning enligt "ljudmetoden", syntetiskt upplagt från del till helhet. Andelen ren läslära i Nu läser vi är liksom tidigare ca hälften. Bokstavsverserna är borta, annars är läsläre-inslagen sig lika. En nyhet jämfört med Nu ska vi läsa är ordbilder, det vill säga frekventa ord som "och" presenterade i sin helhet, oavsett om alla ingående bokstäver introducerats eller ej. Anledningen är att kunna använda dem i texter så tidigt som möjligt. Många av de längre texterna är ändå desamma, liksom det torftiga läslärespråket med sina onaturliga vändningar: i meningen "Mina ser när Sara äter" saknar jag absolut ett "på" som tredje ord $(1977,54)$, och då katten Sara i en bildsekvens stryker sig mot pappas ben beskrivs det otillfredsställande som att "Sara är nära pappas fot." $(1977,58)$ Desto mer imponerande i sin enkelhet är Tors och Lenas ordlek utifrån tre enstaviga trädord (ek-lek-stek, al-mal-smal, en-ren-sten), ett sällsynt exempel på uppmärksammande av språkets form snarare än dess innehåll eller regler (1970, 44; 1977, 57 istället varianten ek-lek-leka-lekt etc.).

Vägen in i Nu läser vi 1970 är förvånansvärt intetsägande: omslagsbilden är orelaterad till huvudinnehållet (två okända barn i lådbil på väg neråt vänster mot orange bakgrund), och titelsidan saknar bild. Första uppslaget visar så Tor och Lena vid skolstaketet, namngivna, vilket anger att de är huvudpersonerna. Sedan följer nitton sidor ren läslära, och först därefter kommer historien igång ordentligt. Första Tor och Lena-episoden är en hemma hos-scen vars utlagda spår av mänsklig närvaro antyder kommande bekantskaper: någons pipa och glasögon, en påbörjad vantstickning med Lenas teckning på väggen som ledtråd (1970, 23; 1977, 46). De nya, stora, detaljerade miljöbilderna är över huvud taget den stora behållningen i Nu läser vi: skolan med kompisar, Tors och Lenas hem, klassrummet. Bilderna är med i etableringen av Tors och Lenas värld och utgör något att begrunda och samtala kring (till läromedlet hör även en bildbok med ytterligare bilder).

Förändringen i samhällsskildring framgår också framför allt med hjälp av Ylva Källström-Eklunds bilder, med sina schvungfulla figu- 
rer i tidens färgskala gult-orange-brunt. Även Vang Nymans illustrationer hade samtida inslag, men nu genomsyras allt av tidstypiska markörer som orange hängselbyxor och klassrummets kuddhörna och blädderblock. Den nya tiden visar sig också i en mer jämlik fördelning av hushållssysslor där mor får lära Tor ro och far bakar. Boken rymmer även nyheter som daghem, adoptivbarn, höghusmiljö, tv-tittande och frånskilda föräldrar (jfr Eilard, kap.5). Hemma hosscenen följs 1970 av en frukostscen, även den med en högst delaktig bild (1970, 24). När texten, särskilt i början, av nödvändighet är rätt enkel, hjälper bilden till att skapa sammanhang till sådant som replikskifte om fat och fil. Denna scen är borttagen 1977 men har istället gett spår i form av "textrester", lösryckta lästräningsmeningar, på flera ställen: "Tor tar mer mat. Tor tar mer te" $(1977,37)$, "Far-far tar fil" (1977, 45). Frukostscenen följs år 1970 logiskt av en högersida med och-konstruktioner utifrån olika konstellationer av vänstersidans familjemedlemmar och matord (fat och mat, fil och mos). Detta fungerar mycket bättre än 1977 års i sammanhanget svårtolkade "Isa och Lisa", "mamma och mor-mor" mitt i alltihop, eftersom frukostmaten är borttagen $(1970,25 ; 1977,40)$. En annan senare borttagen scen är mamma som vid öppet köksfönster läser tidning, medan Tor leker med lok på golvet och Lena tar kaka och fat ur köksskåpen; även den mer naturlig och fungerande än 1977 års motsvarande bildsekvens med pappa som äter kaka (1970, 30f; 1977, 58f). Överlag är kontext, dialog och trovärdighet bättre i 1970 års scenversioner.

Nu läser vi från 1970 innehåller sammantaget fler scener med Tor och Lena och mer fokus på deras hem och familj, men knappt något om skolan förrän mot slutet. 1970 är barnen hemma - fortfarande. Kanske är det mer förlegat och traditionellt, men familjeepisoderna håller samtidigt samman boken och berättelsen. 1977 är det Tors och Lenas klasskamrater som är det centrala. Läsaren leds bland annat in i boken på ett helt annat vis. Vi får från omslaget, över titelbladet och på uppslaget s.8-9 följa inte bara Tor och Lena utan även (mest) deras klasskamrater fram till skolgården. Mycket hejande förekommer, på varandra och på läsaren, som även får barnen presenterade med namn. Det är långt flera, ofta ganska snarlika, personer att hålla reda på. Det finns en stor mängd bilder och korta texter med såväl namngivna som anonyma personer: vid bokstaven V som 1970 exemplifieras med ett fåtal neutrala objekt (våg, vantar osv), förekommer 1977 dessutom Siv som visar val på blädderblock för ett antal klasskamrater. Barnen agerar dock sällan i grupp, istället leker de fortfarande mest två och två. När man skärskådar Tor och Lena ordentligt syns dessutom att de, trots alla klasskamrater, ändå håller sig mest till hem och familj även 1977 - första intrycket bedrar, med andra ord. Men 


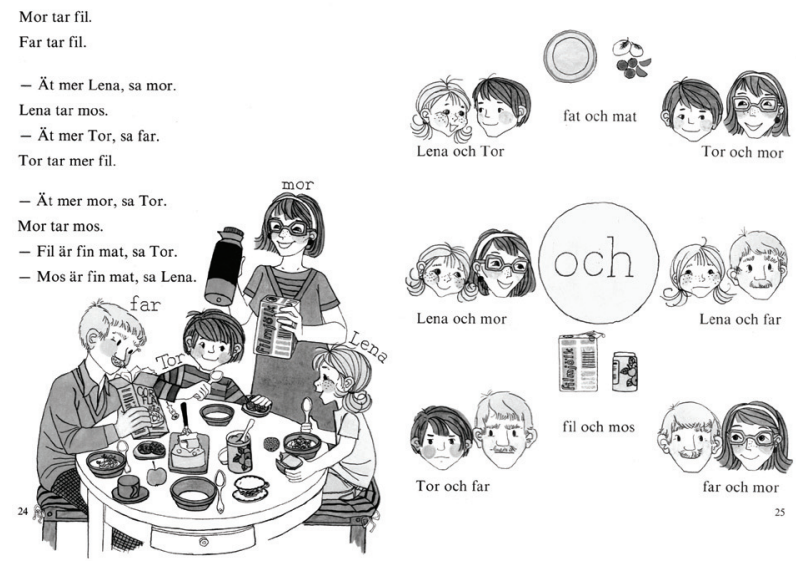

Illustration av @Ylva Källström-Eklund ur Nu läser vi 1970

denna familjetråd har då lite förlorat sitt existensberättigande i texten, genom den ändrade början. Och när familjescener har tagits bort har även helhet och sammanhang påverkats.

Läsebokens förutsättning är en svår balansgång: både lästräning och läsupplevelse. 1977 års Nu läser vi har av oklar anledning ökat sin läsläredel med många fler lösryckta småbilder, ord och meningar, på bekostnad av de längre scenerna. Trots en del tydliggörande kosmetiska förändringar (ökad gradstorlek, kortare rubriker, teckensnitt utan seriffer, liksom småjusteringar i sidlayout, ordning och formuleringar), blir uppslagen därför mer splittrade och röriga. Om anledningen till förändringar är att ytterligare närma innehållet till samtidens barn är det förståeligt om en ålfiske-episod känns föråldrad, men man har ändå valt att behålla ålfisket, fast i lösryckta restmeningar $(1977,66)$. Boken är helt enkelt inte konsekvent, vilket bryter mot läsarens förväntningar på, och behov av, koherens. Förändringarna får också andra effekter, oönskade i en föregivet "lätt" text.

Den mest problematiska effekten av förändringarna i Nu läser vi 1977 är oklara syftningar och ambivalens i pronomenanvändningen, något som tidigare version undviker genom att sätta in frågor och påståenden i ett narrativt sammanhang (scener i text och bild). Det är en mängd personer som skymtar förbi, i såväl berättande textavsnitt som i fristående meningar. Det blir till slut ett rätt anonymt myller, med ibland oklara relationer sinsemellan - vems morfar? Vad har Isa och Lisa för koppling till Tor och Lena? Ett exempel: konstruktioner med "Ser Lena" ingår 1970 i en självförklarande, illustrerad dialog kring ritande med mor och Tor $(1970,26) .1977$ har den istället ersatts av liknande fast lösryckta meningar (1977, 30, 32, möjligen 43). På sidan 30 läser vi: "Lena ser mamma. Ser Lena mer? Vi ser er." Eftersom Lena är ensam och inte tittar mot läsaren; vilka är" vi"? Läsaren, som kollektiv? På sidan 26 är det utöver talaren dessutom oklart vem som 
omtalas: "Vi ser mamma. Du ser mor-mor. Vi ser mer. Vi ser." Någon mamma eller mormor finns inte med på sidan, däremot en pappa. Samma icke-överensstämmelse mellan det texten påstår och bilderna visar finns på sidan 41 . En av frågorna till de fyra bilderna är "Var är mamma och

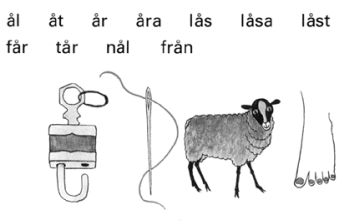

Tore kokar ål. Pappa fiskar ål.

Mina tar ett fat Sara äter mat. Lena åker bil. Erik äter fil.

Lisa äter mos. Isa tar en ros.

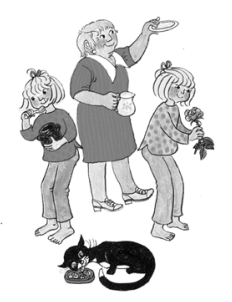

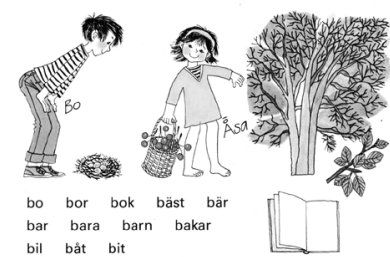
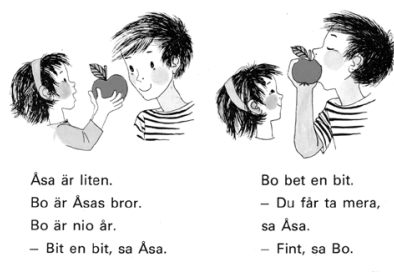
vi?" Den enda avbildade mamman, i busskö, har två små okända barn varav ett över axeln, och inget av dem tittar mot läsaren. Det kräver rejäl fantasi för att betrakta de två småttingarna som ett "vi" i den situationen. På sidan 43 blir man återigen fundersam: "Vi ser en lek-sak. Ni ser en ko. Pappa ser en ek." Varför växla mellan vi och ni? Det ökar känslan av osammanhängande text. Till råga på allt visar bilderna flera kor och flera leksaker.

Med utgångspunkt i begreppen vi och jag - språkliga konstruktioner beroende av vem som talar - kan man konstatera att texten i Nu läser vi från 1977 oavbrutet skiftar position, framför allt i de lösryckta läsmeningarna. Varje ny kort text är skild från de övriga, sammanhanget är aldrig självklart. Det kanske håller läsaren alert, men är också en väldigt otacksam situation. Lättläst? Knappast. Normal språkanvändning styrs av kontexten. Här finns inte någon sådan, och korrelatets bestämning gäckar läsaren. Just detta att det är fråga om en läsebok, med meningar avsedda att läsas för träningens skull, antagligen högt i en gemensam klassrumssituation, kan också krångla till tolkningen. Innebörden av exempelvis frågor förändras beroende på om textens "jag" eller "vi" ligger inom boken - eller om man genom högläsningssituationen inför andra tänker sig sig själv som avsändare. Läsarna som textens "vi" i konstruktioner som "Vi ser mer. Vi ser." är en helt rimlig tolkning. En vanlig titelkonstruktion för en läsebok är uppmaning till aktivitet: Kom och läs! (1999), Läs med oss (1985). Det är då underförstått boken/bokens figurer som uppmanar. Även titlarna Nu ska vi läsa och Vi läser kan tolkas i den riktningen, att det är bokens personer som är "vi". Det stärks av 
att bådas omslag visar figurerna just läsande. I Nu läser vi, däremot, finns ingen sådan antydan, så då kvarstår bara läsarna själva som konstaterar: nu läser vi. Men vi får inte riktigt veta vad.

\section{Vi läser (1989 och 2005)}

Redan Nu ska vi läsa ansåg sig ge läsaren något mer än bara lästräning, men det var då det: förutsättningarna förändras. Under 1970-talet växer kritiken mot den abstrakta och isolerade färdighetsträningen; läsning och skrivning bör istället ses som meningsskapande aktiviteter. Undervisningen bör följaktligen utgå från helheten istället för delarna (Vad händer med läsningen? 32ff; Längsjö \& Nilsson, 69ff. Jfr Lgr80). I betoningen av helhet och läsförståelse får skönlitteraturen också en alltmer betydelsefull roll. De senaste åren har läsundervisningen hämtat inspiration från whole language-metoden, som istället för läseböcker redan från start utgår från litterära, språkligt nivåanpassade texter i storböcker och småböcker, för olika typer av gemensam och självständig läsning (Längsjö \& Nilsson, 75ff). I spåren av detta har utbudet av särskilda lättlästa texter ökat markant, både från läromedels- och barnboksförlag. Nya läseböcker, även sådana med kvarvarande traditionell läslära, har också fått en mer berättande karaktär, med sikte på läsupplevelse.

Från Nu läser vi till Vi läser har läseboken gått från episoder till sammanhängande berättelse, från skildring av kollektiv till fokus på Tor - från läsebok till mer av litterär upplevelse, om man så vill. För texten ansvarar en skönlitterär författare, Ulf Stark, även det ett tecken i tiden (jfr Moni Nilsson Kom och läs 2007, Martin Widmark Jag läser 2008). Scenerna i berättelsen om Tor pendlar mellan hem och skola i en ganska jämn fördelning. Utöver det för läseboken och barnlitteraturen gemensamma skolmotivet lånas nu även andra motiv och figurer in från barnboken: sälja föräldrarnas saker på loppis, hamna på sjukhus (med rullstolsrace à la Nicke Nyfiken), fortsätta rita på golvet när bordet inte räcker till (Olson använder till skillnad från Pippi åtminstone papper). Vi läser anknyter också till tidigare läseboksversioner, som vid cirkusbesöket och de vardagliga morgonscenerna.

Samtidsanpassning finns, utan att sticka ut (jfr Eilard, kap.7). Vanlighet eftersträvas. Lena har blivit storasyster och kompletterats med en lillasyster. Familjen bor i lägenhet, mamma jobbar på posten, pappa kör buss. Man arbetar i skolan, lagar bilen, leker och hittar på lite dumma saker som går bra till slut: lillasyster som stjäl frökens handväska, Tor som utan föräldrarnas vetskap bjuder in hela klassen på kalas. Den familjebaserade vardagskomiken (Eilard kallar det pa- 
rodi; 324) känns igen från samtida barnböcker. Det gäller till exempel framställningen av den snälla men klantiga pappan som hamnar i genanta situationer (jfr t.ex. Sune-böckerna). Familjen tar fortfarande stor plats och blir mer av karaktärer än skolvännerna. Flera scener skildrar föräldrarna även på egen hand (kelas, diskar, dansar, skalar räkor), men relationerna till de närmaste klasskamraterna får också tydligare kontur. Leif Erikssons illustrationer i en snäll, lite anonym stil visar även de, i neutralt igenkännliga miljöer, framför allt personer i samspel. Men till skillnad från tidigare är Tor den absoluta huvudpersonen i både bild och text.

Vi läser är alltså mer narrativ än de tidigare läseböckerna. Det möjliggörs och underlättas på flera vis. Till att börja med har boken blivit längre, närmare 200 sidor mot tidigare 120. Läsläre-delen har samtidigt minskat till en dryg fjärdedel och består nu enbart av tydligt åtskilda bokstavsuppslag med bokstavsvers (igen) och bilder i en annan stil än i de berättande textavsnitten (även annan författare, men samma tecknare). Därutöver ingår några insprängda sagor om Äppelgumman för dem som redan kan läsa eller för läraren att läsa högt, och mot slutet ett par fristående texter av Barbro Lindgren. De senare tas bort i 2005 års version samtidigt som sagorna samlas sist, vilket innebär ytterligare renodling av boken som berättelse om Tor. Flera nya episoder om Tor tillkommer också 2005, särskilt i början av boken, vilket bidrar till en tätare och mer sammanlänkad historia. Till sammanvävningen bidrar även den regelbundna, tydliga layouten inom de berättande textavsnitten. Fokus på den berättande texten uppnås även genom frånvaron av fristående ord och meningar. De enda lösryckta orden i Vi läser hittas på uppslagen om Tor, i en markerad blå ruta, och har direkt relevans för texten: t.ex. sen, sena, nos, nosa $(1989,44)$. Till det kommer visserligen en avsevärt ökad mängd ordbilder att lära sig känna igen i sin helhet, men dessa är en nödvändig kompromiss i strävan efter intresseväckande läsning så fort som möjligt. Bilderna engageras också i berättandet mera än tidigare. För att få del av hela handlingen krävs uppmärksamhet även på visuella detaljer, som var väskan kommer ifrån som Siv hittar hemma hos Tor $(1989,37)$.

Den främsta anledningen till att Vi läser lyckas vara mer berättande än tidigare versioner ligger ändå i dess nivåindelade text: enklare vänstersidor för de absoluta nybörjarna och lite mer på högersidorna för de som redan kan. Det går inte att hoppa över högersidorna, då blir det oförklarliga luckor i handlingen, och det är tänkt att alla elever får del av hela texten, om inte genom egen läsning så genom andras. A- och B-texterna flyter i slutet ihop till en gemensam, icke- 

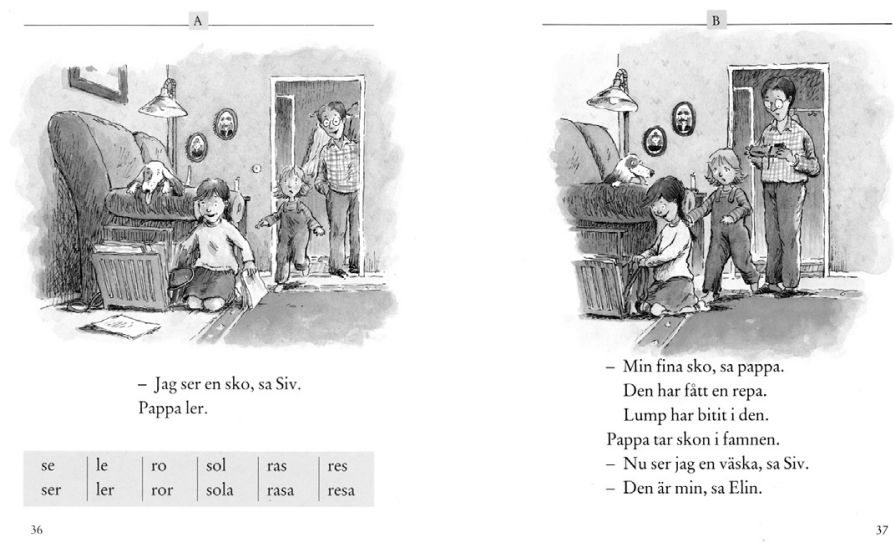

Illustration av CLeif Eriksson ur Vi läser, 1989

nivåindelad text. Denna anpassning till elevernas olika förkunska per är ett växande fenomen (se t.ex. Läs med oss 1985, Läsgåvan 1995, Bumerang 2005. Jfr Längsjö \& Nilsson, s.80f). Nivåindelad text är ett försök att skapa en gemensam bas där alla kan vara med. Det trycker alla lärarhandledningar och liknande också på: balansen mellan individ och gemenskap. Nybörjarna besitter olika kunskap och intresse för läsning vilket kräver individualisering, men samtidigt framhålls vikten av att hålla ihop "klassrumsgemenskapen". Samtal betonas, till exempel kring den mataffärsinteriör med intraikoniska texter som lagts in mitt i inledningen till Nu läser vi 1977, före själva läsinlärandet (en enklare förlaga till bilden finns redan i Bildboken 1970). Läseboken fyller här ett utjämnande syfte och utgör något att samlas kring. Den är uppenbarligen tänkt för kollektiv aktivitet. Jämför med information i innehållsförteckningen till Vi läser som "Vi får möta Tor och hans familj, hans klass och hans fröken." Vi, som läsarkollektiv - precis som konstaterats ovan vad gäller läsebokstextens tilltal.

Läsning framstår annars gärna som en privat, individuell aktivitet, men som läsinlärning är det inte det: lärande sker i samspel med andra. Som när Tor lär Lump läsa, eller egentligen tränar sig själv: "Nu lilla Lump, ska vi läsa ett slag, och se vad vi lärt oss, min hund och jag." $(1989,190)$. Tor anpassar till och med situationen till sin medpart genom att välja relevanta ord: räv, vov (1989, 74 resp. 190). Vi läser handlar också mer än tidigare om läsning. Från förvånande lite i tidigare versioner tillkommer 1989 ordentliga försök att framställa läsning och skrivning som meningsfulla, kommunikativa aktiviteter inte bara 
för skolan utan även privat, som fotoalbumets bildförklaringar, klassen som skriver på Tors gips eller fasters vykort. Inte minst börjar och slutar ju (plus lite däremellan) hela Vi läser 1989 med Tors läsning - se omslagsbilden. Avslutningsorden om Tors sommarplaner bekräftar den direkta personliga nyttan med att kunna läsa och skriva. "Han ska skriva ett vykort till Siv. Och han ska läsa en bok." $(1989,185)$.

\section{Slutord}

För alla tre böcker gäller att framför allt illustrationerna bidrar till stämning och samtidskänsla; i dem markeras tidsandan och ges en skymt av skiftande klassrumspraktiker. Men även i övrigt är läseböckerna barn av sin tid. 1970-talets Nu läser vi exemplifierar medvetet olika företeelser. Inte minst relativiserar och avpersonifierar den, genom sitt kollektiva, decentraliserade fokus, relationer som "vi" och "mamma". I Vi läser handlar det istället om riktad, känslomässig identifikation med en utvald huvudperson, i samklang med bland annat barnbokens ökande fokus på jaget och individen - Eilard ser även samband mellan Vi läsers barn- och individperspektiv och tidens individualiserade undervisningsideal (Eilard, 306).

Trots förmodat förändringsbehov med jämna mellanrum (innehållsligt, men framför allt metodiskt) är skillnaden mellan de undersökta läseböckerna emellertid många gånger mindre än väntat. Tillagda eller borttagna scener och övningar har till exempel ibland bara flyttat till eller från någon annan bok i materialet: Tor och pappa sitter fortfarande och ror, fast i Övningsbok med extra lästräning. Udda för läseböcker är också deras, trots utpräglad tidstillhörighet, långa tillämpning: Nu läser vi från 1977 går fortfarande att köpa. Läseboksläsning är ju också, utöver en kollektiv sysselsättning, en säreget utdragen och repetitiv historia: första årskursens läsebok är avsedd att räcka just ett år.

Läseboken är en speciell och ambivalent textgenre. Hur den än är utformad har en läsebokstext vissa stildrag och begränsningar som är svåra att komma ifrån, även om försök görs att mildra effekten exempelvis med ordbilder för att underlätta meningsfulla texter, eller sammanbindning av korta textstycken med hjälp av återkommande figurer. Även om man de senaste åren har försökt göra läseboken mindre läroboksaktig går det aldrig att genomföra till fullo; närmandet till litteraturen blir aldrig mer än ett sken. Jämför med vad lärarhandledningen till Vi läser säger om bokens sista kapitel: "Man kan välja att låta barnen läsa s 176-183 som ren upplevelseläsning utan att bearbeta texten." (Vi läser. Första lärarboken 1990, 111) Med all önskvärd tydlighet framgår att hur berättelseliknande läseboken 
än är, så blir det aldrig samma sak som en "riktig" bok. Den språkliga tvångströjan sitter kvar, liksom den instrumentella textanvändningen. Så det sammanhållande kittet i en läsebok, oavsett form, är ändå målet att har jag läst hela boken, så kan jag läsa (alla bokstäver är genomgångna). Som barn utsätts man för den, helt enkelt, på gott och ont, och ens första läsebok är inpräglad i medvetandet minst lika hårt som barndomens övriga läsning. Och läsebokstitlar anknyter förstås av naturliga skäl så gott som alltid i positiv ton till läsning: Alla vill läsa (1995), LäsDax (2008), Läsgåvan (1995), Läslustan (1982). Elsa Beskows läsebok från 1935 uppmanar i mer öppen frågeform: Vill du läsa? Som om man skulle ha något val...

\section{Bibliografi}

Borrman, Stina, Salminen, Ester, Wigforss, Frits och ill. Nyman, Ingrid Vang. Nu ska vi läsa: första boken. Stockholm: Almqvist \& Wiksells skolböcker/Geber, 1948.

Borrman, Stina, Salminen, Ester, Wigforss, Vera, Matthis, Kjersti och ill. Källström-Eklund, Ylva. Nu läser vi A: läseboken. Stockholm: Almqvist \& Wiksell, 1970.

Borrman, Stina, Mattis, Kjersti, Salminen, Ester, Wigforss, Vera och ill. Källström-Eklund, Ylva. Nu läser vi A: läseboken. Femte, omarbetade upplagan. Stockholm: Almqvist \& Wiksell, 1977.

Borrman, Stina, Stark, Ulf, Bolldén, Kerstin, Dalmo, Mari-Anne och ill. Eriksson, Leif. Vi läser: första boken. Stockholm: Almqvist \& Wiksell, 1989.

Borrman, Stina, Stark, Ulf, Bolldén, Kerstin, Dalmo, Mari-Anne och ill. Eriksson, Leif. Vi läser: första boken. Andra, omarbetade upplagan. Stockholm: Almqvist \& Wiksell, 2005.

Clarhäll, Anita Welin, "'Att koka soppa på en spik': Ingrid Vang Nyman och Nu ska vi läsa". I Ingrid Vang Nyman, red. Lena Törnqvist och Sture Åkerström. Kungliga bibliotekets utställningskatalog nr 139. Stockholm och Vimmerby: 2003, s.66-69.

Eilard, Angerd. Modern, svensk och jämställd: om barn, familj och omvärld $i$ grundskolans läseböcker 1962-2007. Avh. Lund. Malmö studies in educational sciences 38. Malmö: 2008.

Lindell, Ebbe. Gam-la läs-lä-ror. Malmö Skolmuseums utgåva nr 23.

Malmö: 1999.

Längsjö, Eva och Nilsson, Ingegärd. Att möta och erövra skriftspråket: om läsoch skrivlärande förr och nu. Lund: Studentlitteratur, 2005.

Löfgren, Eva Margareta. "Historien om Sörgården". I Från Sörgården till Lop-nor: klassiska läseböcker i ny belysning, red. Bo Ollén. Skrifter utgivna av Svenska barnboksinstitutet nr 57. Stockholm: Carlsons, 1996, s.188-239.

Vad händer med läsningen? En kunskapsöversikt om läsundervisningen i Sverige 1995-2007. Rapport 304. Stockholm: Skolverket, 2007.

Keywords: Läseböcker 